\title{
PEMANFAATAN TANDAN KOSONG SAWIT DAN RUMPUT SEBAGAI BAHAN KOMPOS DI PT BUKIT ASAM, SUMATERA SELATAN
}

\author{
Utilization of Empty Fruit Bunch and Grass As Compost Raw Material in PT Bukit Asam, \\ South Sumatera
}

\author{
Arief Juniarto $^{1 *}$, Irdika Mansur ${ }^{2}$, Arief Sabdo Yuwono ${ }^{3}$
}

(Diterima November 2017/Disetujui Desember 2017)

\begin{abstract}
PT Bukit Asam had strategies to improve soil fertility in the ex-mine land using compost. The amount of compost added to the soil depend on the extent of reclamation area. Oil palm empty fruit bunch and grass are highly potential to be used as the compost materials in reclamation area. The objectives of the research were to characterize the compost from oil palm empty fruit bunch and grass, and to compare the suitability between the result of this research and nasional standard compost. Oil palm empty fruit bunch and grass were obtained from PT Bumi Sawindo Permai and reclamation area of PT Bukit Asam, respectively. Composting site was located in the ex-mine land of PT Bukit Asam. Composting method used passively aerated static pile system. The results showed that the compost characteristic of oil palm empty fruit bunch compost had a dark yellowish brown color, $\mathrm{pH}$ at 9.3, C/N ratio at 14, and nutrients (C-Organic, $N, P, K$, and Mn Total). The compost characteristics of grass had a very dark brown, $p H$ at 7.3, C/N ratio at 7, and nutrients (C-Organic, $N, P, K$, and $M n$ Total). The compost from oil palm empty fruit bunch and grass were in accordance with the national standard of compost.
\end{abstract}

Key words: empty fruit bunch, grass, compos

\section{PENDAHULUAN}

Sektor usaha pertambangan pada satu sisi memberikan sumbangan bagi pendapatan negara, dan di sisi lain menyebabkan permasalahan lingkungan. Permasalahan yang terjadi antara lain adalah rusaknya struktur tanah, $\mathrm{pH}$ tanah menjadi masam, ketersediaan bahan organik dan nutrisi hara yang rendah, tingginya kandungan logam berat serta polusi air dan udara (Oktavia et al. 2012; Rodriguez-Vila et al. 2015, Sevilla-Perea dan Mingorance 2015). Upaya menata, memulihkan, dan memperbaiki kualitas lingkungan pasca tambang dijalankan melalui reklamasi.

Salah satu kegiatan reklamasi lahan bekas tambang untuk memperbaiki kesuburan tanah yang telah berjalan hingga saat ini melalui penggunaan pupuk organik atau kompos(Sizmur et al. 2011, Madejon et al. 2014). Kompos dapat memperbaiki sifat fisik, kimia, dan biologi tanah (Cunha-Queda et al. 2007, Martinez-blanco et al. 2009, Tejada et al. 2009, Belyaeva et al. 2012). Penelitian terdahulu menunjukkan kompos memberikan pengaruh

\footnotetext{
${ }^{1}$ Staff Pengajar Program Studi Rekayasa Kehutanan ITERA

* Penulis korespondensi: e-mail: ariefjuniarto@gmail.com

2 Staff Pengajar Dept. Silvikultur, Fakultas Kehutanan IPB

3 Staff Pengajar Dept. Teknik Sipil dan Lingkungan, Fakultas Teknologi Pertanian IPB
}

nyata terhadap pertumbuhan semai mahoni (Swietenia macrophylla) pada media tanah bekas tambang emas (Wasis dan Sandrasari 2011).

Penggunaan pupuk organik dalam reklamasi lahan bekas tambang telah dijalankan perusahan negara pertambangan batubara, PT Bukit Asam (PT BA) di Tanjung Enim, Sumatera Selatan. Kebutuhan pupuk organik di PT BA mencapai 1500 ton/tahun dengan luas rencana kerja per tahun mencapai $100-150$ ha (PT BA 2013). Kebutuhan pupuk organik saat ini berasal dari pupuk bokashi hasil olahan kelompok mitra binaan PT BA dengan kapasitas produksi mencapai 600-800 ton/tahun. Kebutuhan kompos secara rutin dalam skala besar tersebut menyebabkan permasalahan berupa penurunan kualitas produk dan kuantitas ketersediaan yang tidak stabil, sehingga perlu alternatif bahan organik yang mampu menunjang kebutuhan pupuk organik di PT BA secara mandiri. Potensi bahan organik yang memungkinkan untuk produksi skala industri di PT BA yaitu tandan kosong sawit dan rumput sebagai bahan baku kompos. Hal ini karena melimpahnya limbah tandan kosong sawit dari PT Bumi Sawindo Permai (PT BSP), anak perusahaan PT BA. Selain itu, potensi rumput di areal Izin Usaha Pertambangan (IUP) juga melimpah dan berpotensi sebagai bahan baku kompos. Oleh karena itu, tujuan penelitian ini untuk mengkarakterisasi kompos tandan kosong sawit dan rumput serta membandingkan kesesuaian kualitas kompos menurut standar mutu nasional. 


\section{METODE PENELITIAN}

\section{Waktu dan Tempat}

Penelitian dilaksanakan pada bulan Mei - Juni 2016 di PT BA. Pengujian parameter kompos dilakukan di Laboratorium Pengujian Batu Bara PT BA dan Laboratorium Tanah dan Tanaman SEAMEO BIOTROP, Bogor.

\section{Alat dan Bahan}

Bahan kompos yang digunakan adalah tandan kosong sawit yang berasal dari PT BSP dan potongan rumput yang berasal dari areal IUP PT BA. Alat pengomposan berupa pipa perforasi dengan diameter $10.16 \mathrm{~cm}$, pipa ukur suhu dengan diameter $1.91 \mathrm{~cm}$ sepanjang $1.5 \mathrm{~m}$, bor listrik, termometer, dan pita meter.

\section{Prosedur Penelitian}

Metode pengomposan menggunakan pengaturan aerasi, "Passively Aerated Static Pile" dengan cara menumpuk semua bahan kompos dan dibiarkan terdekomposisi secara alami, sehingga proses

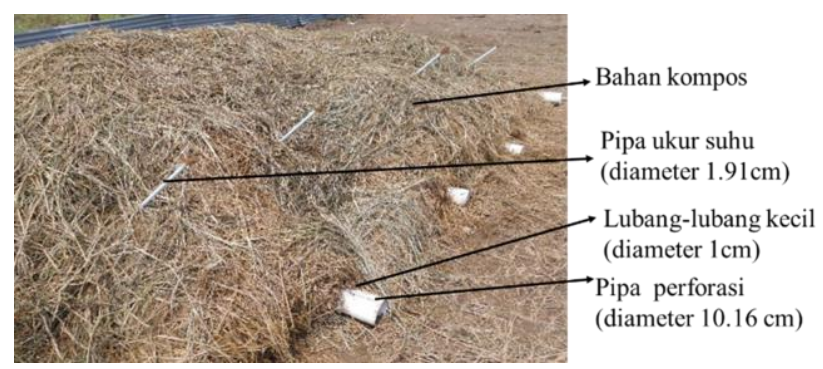

Gambar 1 Teknik pengomposan Passively Aerated Static Pile pengomposan berjalan dengan sendirinya (Cooperband 2002, Yu et al. 2009, Yuwono et al. 2013). Adapun prosedur penelitian meliputi penyiapan bahan, pembentukan tumpukan, dan pengumpulan data.

Penyiapan bahan. Penyiapan bahan kompos dilakukan dengan mengumpulkan tandan kosong sawit segar dan rumput. Tandan kosong sawit tidak perlu dicacah karena sudah berbentuk irisan-irisan saat keluar dari mesin pabrik PT BSP. Rumput juga tidak perlu dicacah karena sudah berbentuk potongan-potongan. Jenis rumput yang diperoleh di areal IUP PT BA adalah Cyperus esculentus. Selanjutnya, penyiapan pipa perforasi dibuat dengan membuat lubang pada pipa berdiameter 1 $\mathrm{cm}$ dan jarak antar lubang sebesar 4-5 cm. Masing-masing bahan kompos ditimbang, kemudian dilakukan penumpukan. Pada penelitian ini tidak menambahkan aktivator pengomposan atau kotoran ternak.

Pembetukan tumpukan. Tandan kosong sawit dan rumput ditumpuk secara terpisah di atas lahan pengomposan dan dibiarkan terbuka. Ukuran tumpukan masing-masing sekitar $3 \times 5.8 \mathrm{~m}$ dengan tinggi $1.2 \mathrm{~m}$. Pada bagian dasar tumpukan ditempatkan 5 buah pipa perforasi (Gambar 1). Pipa perforasi bertujuan pengganti aerasi dan meniadakan pembalikan, sehingga bahan kompos terdekomposisi secara aerobik. Selain itu, ditempatkan pipa ukur suhu berdiameter $1.91 \mathrm{~cm}$ secara diagonal sebanyak 4 titik sebagai jalan masuk termometer untuk mengukur suhu di dalam tumpukan (Gambar 1). Selanjutnya, bahan kompos disiram air sekali pada awal pengomposan dengan tingkat kebasahan $45-60 \%$ dari total berat atau kondisi basah yang cukup jika diperas dengan tangan (Cooperband 2002).

Pengumpulan data. Masa pengamatan dilaksanakan selama 8 minggu. Pengumpulan data meliputi: perubahan warna yang diamati secara visual setiap 2 minggu sekali; suhu diukur setiap hari sekali, kemudian diambil nilai

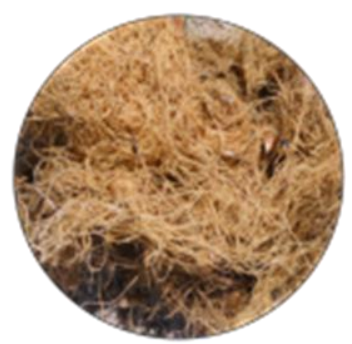

(a)

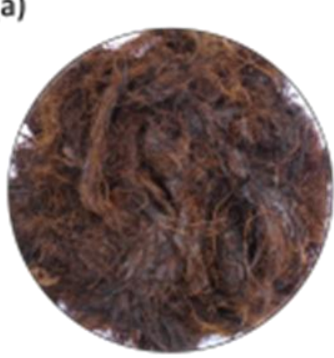

(d)

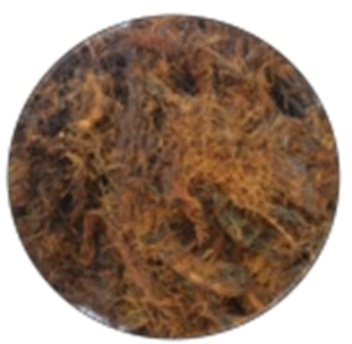

(b)

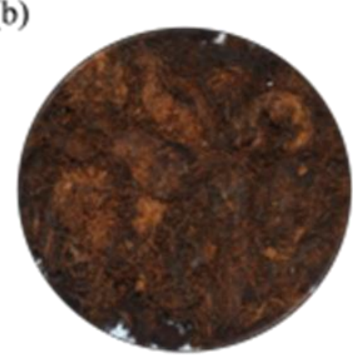

(e)

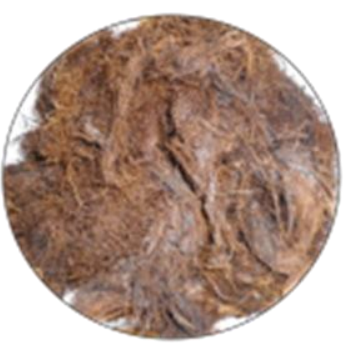

(c)

Gambar 2 Perubahan warna pengomposan tandang kosong sawit pada pekan ke: 0 (a); 2 (b); 4 (c); 6 (d); 8 (e) 
rata-rata dari 4 titik tersebut; $\mathrm{pH}$ dan rasio $\mathrm{C} / \mathrm{N}$ yang dilakukan melalui analisis laboratorium setiap 2 minggu sekali. Selain itu, pengukuran unsur hara makro (N Total, P Total, K Total, Ca Total, dan Mg Total) dan unsur hara mikro (Fe Total dan Mn Total) dilakukan melalui analisis laboratorium pada akhir pengamatan. Sampel untuk pengukuran $\mathrm{pH}$, rasio $\mathrm{C} / \mathrm{N}$, unsur hara makro dan mikro merupakan komposit 4 titik sampel kompos di dalam tumpukan mengacu pada 4 titik pipa ukur suhu.

\section{HASIL DAN PEMBAHASAN}

Kelayakan kualitas kompos dipengaruhi oleh faktorfaktor kestabilan dan kematangan kompos. Kestabilan dan kematangan kompos ditunjukkan oleh perubahan warna, suhu, dan rasio $\mathrm{C} / \mathrm{N}$ serta kandungan unsur hara makro dan mikro.

\section{Warna Kompos}

Perubahan warna telah terjadi pada material tandan kosong dan rumput selama proses pengomposan. Warna tandan kosong sawit setelah 8 minggu pengomposan berubah dari kuning menjadi dark yellowish brown (Gambar 2). Warna rumput berubah dari hijau menjadi very dark brown (Gambar 3). Penetapan standar warna berdasarkan panduan warna tanah, Munsell color soil chart. Perubahan warna pada tandan kosong sawit dan rumput menunjukkan perubahan tingkat kematangan bahan material kompos. Tolok ukur sederhana ditunjukkan dengan perubahan warna secara bertahap yang semakin gelap dari setiap waktu pengamatan yang berkala (Antil et al. 2014). Secara umum kompos yang sudah matang dapat dicirikan dengan kompos bewarna cokelat gelap hingga hitam (Rynk el al. 1992). Hasil kompos secara aerobik berupa bahan yang menyerupai tanah berwarna hitam dan kecokelatan, remah dan suhu normal (Yuwono 2007).

\section{Suhu Tumpukan Bahan Kompos}

Pengomposan rumput pada suhu $38^{\circ} \mathrm{C}-40^{\circ} \mathrm{C}$ merupakan fase mesophilic yang terjadi selama 6 hari sejak awal hari pengamatan (Rynk et al. 1992). Selanjutnya, fase thermophilic pada rumput ditandai pada suhu klimaks mencapai $47^{\circ} \mathrm{C}$ pada hari ke-15. Pengomposan tandan kosong sawit mengalami durasi fase thermophilic yang lebih lama dibanding rumput.

Hal ini ditunjukkan suhu tandan kosong sawit diatas $40^{\circ} \mathrm{C}$ berlangsung hingga hari pengamatan ke-46. Peningkatan suhu di fase thermophilic (suhu $40-65^{\circ} \mathrm{C}$ ) ini diduga terjadi karena peningkatan laju dekomposisi bahan material kompos oleh aktivitas bakteri dan jamur thermophilic (Insam dan de Bertoldi 2007). Kestabilan kompos rumput terjadi sejak hari pengamatan ke-32, sedangkan pada tandan kosong sawit terjadi pada hari pengamatan ke-54. Kompos terindikasi stabil saat suhu pengomposan sama dengan suhu ambien (Rynk et al. 1992).

\section{pH Kompos}

Standar mutu nasional kompos pada parameter $\mathrm{pH}$ bernilai 7-9. Secara umum pengomposan tandan kosong sawit dan rumput masuk dalam standar mutu $\mathrm{pH}$ kompos. Perubahan $\mathrm{pH}$ selama pengomposan tidak terjadi secara signifikan. Sejalan dengan Kalamdhad et al. (2009) pH dedaunan pohon tidak mengalami perubahan nyata selama proses pengomposan. Umumnya $\mathrm{pH}$ bahan organik berkisar 5.5-8.0 mudah dikomposkan, karena pada kisaran tersebut bakteri bekerja lebih optimal. Nilai $\mathrm{pH}$ tinggi yang berasosiasi dengan temperatur yang semakin

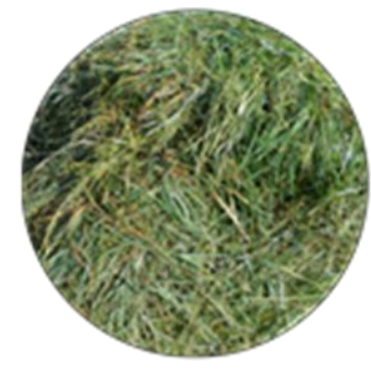

(a)

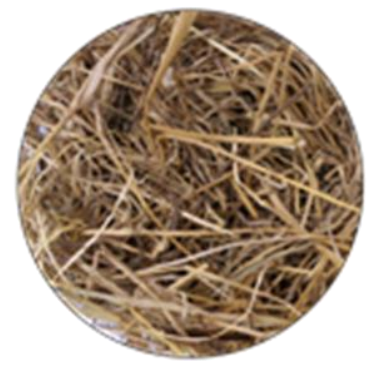

(b)

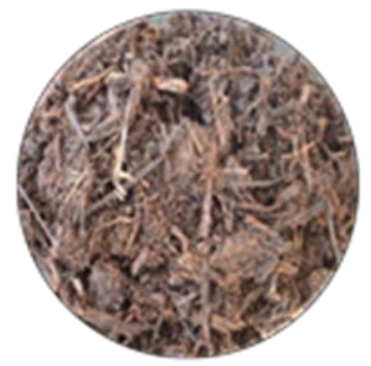

(c)

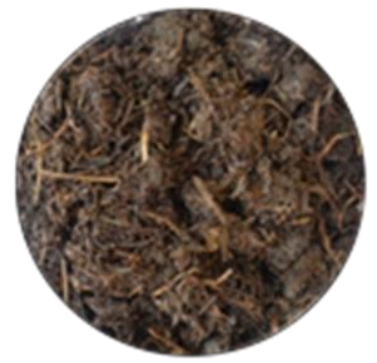

(d)

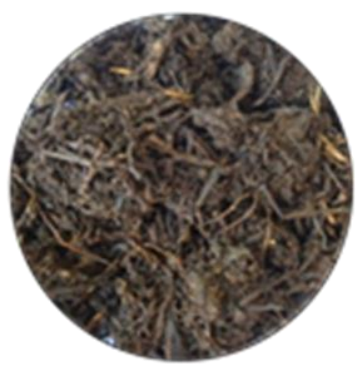

(e)

Gambar 3 Perubahan warna pengomposan rumput pada pekan ke: 0 (a); 2 (b); 4 (c); 6 (d); 8 (e) 


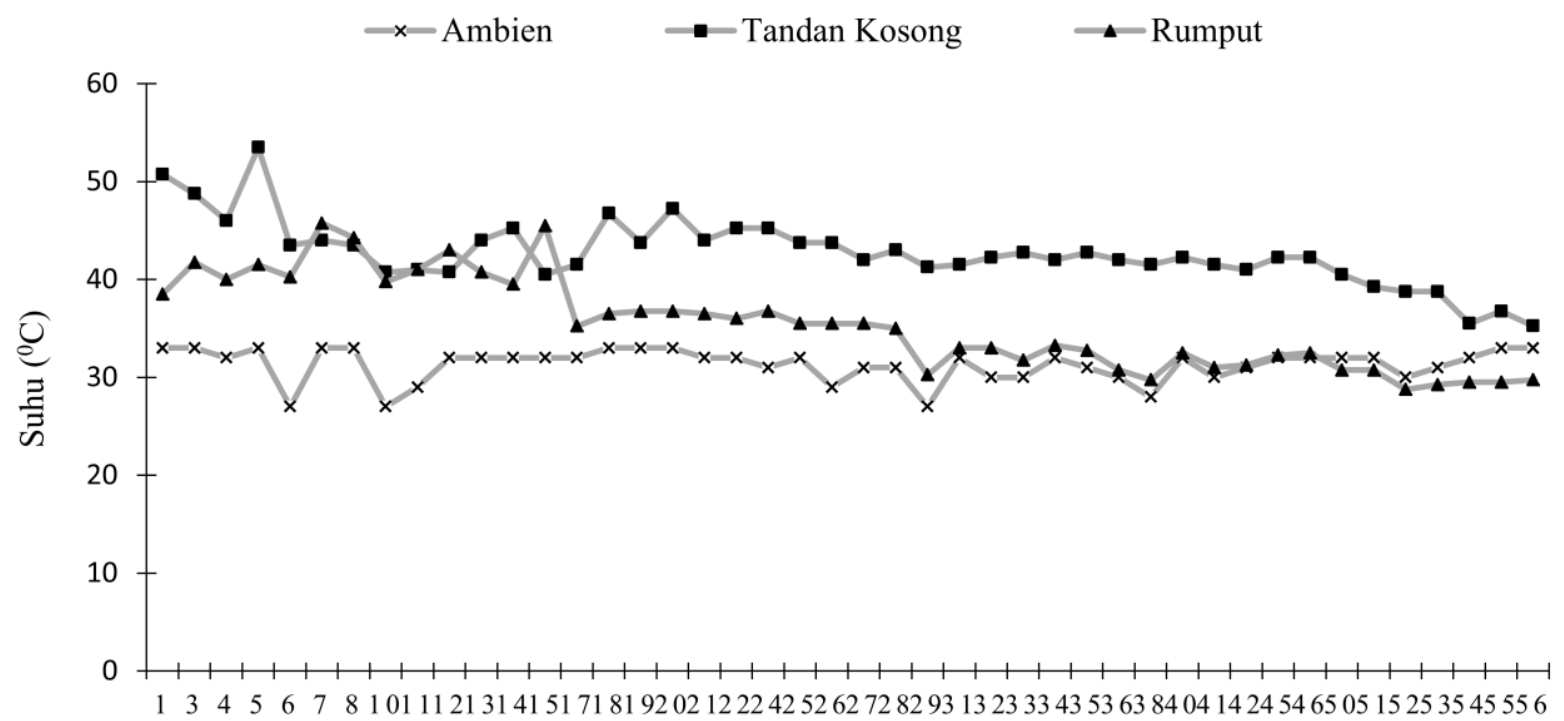

Hari pengamatan ke-

Gambar 4 Suhu pengomposan tandan kosong sawit dan rumput

tinggi menyebabkan volatilisasi amonia selama terjadi aerasi dalam proses pengomposan (Diaz \& Savage 2007).

\section{Rasio C/N}

Rasio C/N pada tandan kosong dan rumput mengalami penurunan bertahap pada setiap pekan pengamatan. Peraturan Menteri Pertanian No 70 tahun 2011 menunjukkan bahwa standar mutu kompos pada parameter rasio $\mathrm{C} / \mathrm{N}$ berkisar $15-25$. Kompos tandan kosong sawit mencapai standar mutu (rasio $\mathrm{C} / \mathrm{N}$ sebesar 14-25) sejak pekan ke-4 atau membutuhkan waktu selama 30 hari (Gambar 6). Berbeda menurut Thambirajah et al. (1995), pengomposan tandan kosong sawit saja sebagai kontrol selama 60 hari memiliki rasio $\mathrm{C} / \mathrm{N}$ sebesar 24 (rasio C/N awal 52). Baharuddin et al. (2009), menujukkan bahwa hasil kompos tandan kosong sawit ditambah Palm Oil Mill Effluent (POME) pada selang 40 hari diperoleh rasio $\mathrm{C} / \mathrm{N}$ sekitar 20 (rasio $\mathrm{C} / \mathrm{N}$ awal 52).

Parameter rasio $\mathrm{C} / \mathrm{N}$ rumput sebesar 22 sesuai dengan standar mutu kompos sejak pekan ke-2 (Gambar 6). Hal ini sejalan menurut Kalamdhad et. al. (2009), menunjukkan bahwa pengomposan sampah dedaunan selama 20 hari dengan rasio $\mathrm{C} / \mathrm{N}$ sebesar 16 (rasio $\mathrm{C} / \mathrm{N}$ awal 22). Selain itu, Zhang dan Sun (2016) menunjukkan bahwa pengomposan sampah dedaunan mencapai kematangan selama 22 hari. Nilai rasio $\mathrm{C} / \mathrm{N}$ antara dedaunan dan rumput hampir sama.

Dekomposisi tandan kosong sawit membutuhkan waktu yang lebih lama dibanding dengan rumput. Hal ini karena kandungan lignin yang tinggi pada tandan kosong sawit. Kandungan tandan kosong sawit yaitu selulosa $52.5 \pm 6.5 \%$; hemiselulosa $28.8 \pm 1.1 \%$; dan lignin 17.1 $\pm 3.6 \%$ (Baharuddin et al. 2009). Kandungan lignin tandan kosong sawit hampir mendekati lignin kayu yang bekisar 18\%-30\% (Insam \& de Bertoldi 2007), sedangkan lignin rumput sekitar $12 \%$ (Tuomela et al. 2000).

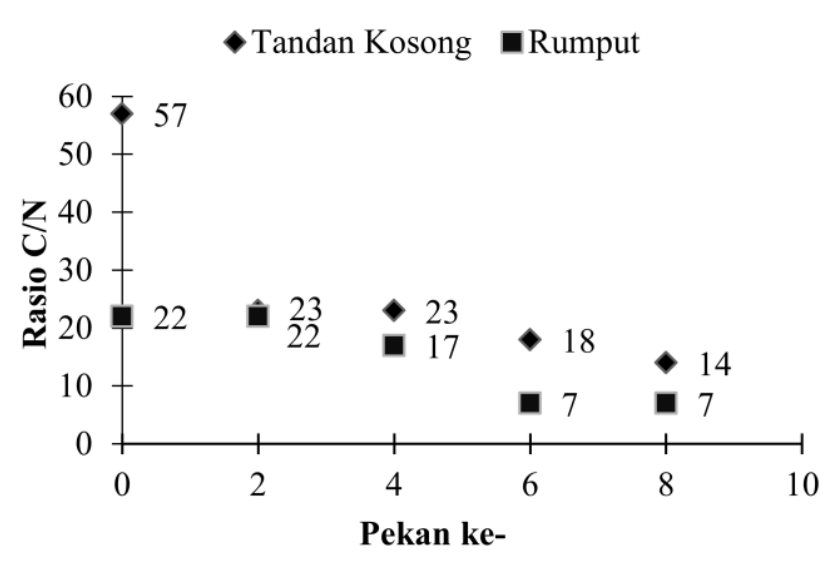

Gambar 6 Perubahan rasio C/N pada pengomposan tandan kosong sawit dan rumput

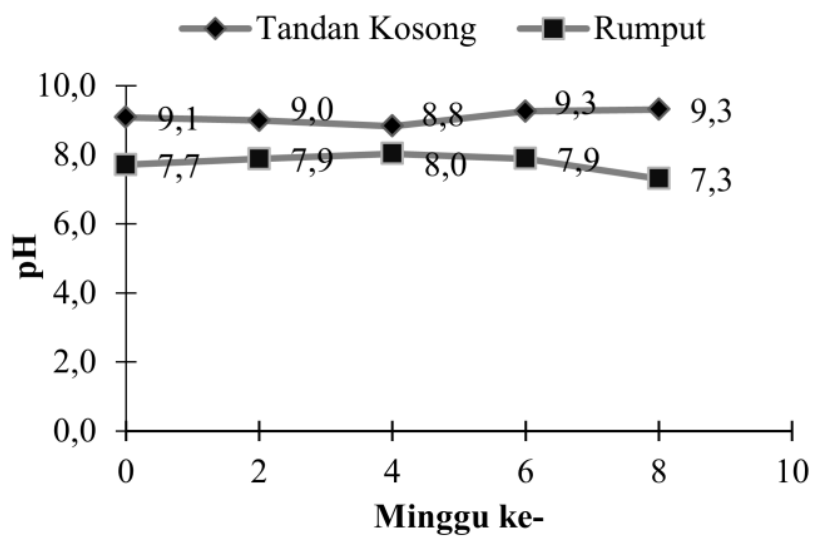

Gambar $5 \mathrm{pH}$ pengomposan tandan kosong sawit dan rumput 


\section{Parameter Unsur Hara}

Hasil penelitian menunjukkan unsur hara makro dan mikro baik pada kompos tandan kosong sawit maupun rumput, telah memenuhi standar mutu kompos menurut Peraturan Menteri Pertanian No. 70 tahun 2011 tentang pupuk organik, pupuk hayati dan pembenah tanah (Tabel 1). Unsur K Total baik pada kompos tandan kosong sawit dan rumput memiliki nilai terbesar dibanding dengan unsur hara makro yang lainnya ( $\mathrm{N}$ Total dan $\mathrm{P}$ Total), meskipun kompos biasanya ditandai dengan konsentrasi $\mathrm{K}$ yang rendah (Tabel 1) (Insam \& de Bertoldi 2007). Selain itu, kompos rumput memiliki kandungan logam berat $\mathrm{Mn}$ yang lebih tinggi dibanding kompos tandan kosong sawit. Ini menunjukkan rumput Cyperus esculentus di lahan bekas tambang PT BA menjadi akumulator logam berat, unsur Mn. Hasil uji laboratorium menunjukkan kandungan Mn pada tanah lokasi rumput sebesar $58 \mathrm{ppm}$, tetapi kandungan Mn pada daun rumput sebesar 2547 ppm. Hal ini sejalan dengan Yadav dan Chandra (2011), C. esculentus diteliti sebagai akumulator Mn pada wetland alami di India dengan tingkat penyerapan logam Mn pada daun sekitar $350 \mathrm{mg} / \mathrm{kg}$.

\section{SIMPULAN DAN SARAN}

\section{Simpulan}

Karakteristik kompos tandan kosong sawit memenuhi standar mutu nasional dari penelitian ini adalah warna dark yellowish brown, $\mathrm{pH}$ sebesar 9.3, rasio $\mathrm{C} / \mathrm{N}$ sebesar 14, dan memenuhi standar unsur hara makro dan mikro. Kompos rumput memiliki karakteristik warna very dark brown, $\mathrm{pH}$ sebesar 7.3, rasio $\mathrm{C} / \mathrm{N}$ sebesar 7, dan unsur hara makro dan mikro yang juga memenuhi standar mutu nasional.

Tabel 1 Parameter unsur hara pada kompos tandan kosong sawit dan rumput

\begin{tabular}{|c|c|c|c|}
\hline $\begin{array}{l}\text { Parameter } \\
\text { Kompos }\end{array}$ & $\begin{array}{c}\text { Tandan } \\
\text { Kosong } \\
\text { Sawit } \\
\end{array}$ & Rumput & $\begin{array}{c}\text { Standar } \\
\text { mutu } \\
\text { kompos* }\end{array}$ \\
\hline C-Organik (\%) & 36.8 & 21.8 & $\underset{15}{\operatorname{minimal}}$ \\
\hline N Total (\%) & 2.7 & 3.1 & Total (N \\
\hline P Total (\%) & 0.7 & 1.2 & $\begin{array}{c}+\mathrm{P}_{2} \mathrm{O}_{5}+ \\
\left.\mathrm{K}_{2} \mathrm{O}\right)\end{array}$ \\
\hline K Total (\%) & 11.3 & 9.4 & $\begin{array}{c}\text { minimal } \\
4 \%\end{array}$ \\
\hline Mn Total (ppm) & 331 & 2547 & $\begin{array}{c}\text { maksimal } \\
5000\end{array}$ \\
\hline
\end{tabular}

\section{Saran}

Produksi kompos berbahan baku tandan kosong sawit dan rumput dengan metode passively aerated static system dapat diterapkan di PT Bukit Asam, Sumatera Selatan. Perlu dilakukan penelitian lebih lanjut pada aspek biaya produksi yang dikeluarkan untuk memproduksi kompos tandan kosong sawit dan rumput.

\section{DAFTAR PUSTAKA}

Antil RS, Raj D, Abdalla N, Inubushi K. 2014. Physical, Chemical, and Biological Paramaeters for Compost Maturity Asssesment: A Review. Maheswari DK, editor. Composting for suistanable agriculture. Volume 3. Sustainable Development and Biology. Switzerland (AUS): Springer.

Baharuddin AS, Wakisaka M, Shirai Y, Abd AS, Abdul RNA, Hassan MA. 2009. Co-composting of empty fruit bunches and partially treated palm oil mill effluents in pilot scale. Int J Agric Res. 4(2):69-78

Belyaeva ON, Haynes RJ, Sturm EC. 2012. Chemical, physical and microbial properties and microbial diversity in manufactured soils produced from cocomposting green waste and biosolids. Waste Manage. 32:2248-2257.

Cooperband L. 2002. The art and science composting. Wisconsin (US): Center for Integrated Agriculutural Ecosystem.

Cunha-Queda AC, Riberio HM, Ramos A, Cabral F. 2007. Study of biocemical and microbiological parameters during composting of pine and eucalyptus bark. Bioresour Technol. 98:3213-3220.

Diaz LF, Savage GM. 2007. Factor that affect the process. Di dalam : Diaz LF, de Bertoldi M, Bidlingmaier, editor. Compost Science and Technology. Volume 8. Waste Management Series. Oxford (GB): Elsevier Science.

Insam H, de Bertoldi M.2007. Mycrobiology of the composting process. Di dalam : Diaz LF, de Bertoldi $\mathrm{M}$, Bidlingmaier, editor. Compost Science and Technology. Volume 8. Waste Management Series. Oxford (GB): Elsevier Science.

Kalamdhad AS, Singh YK, Ali M, Khwairakpam M, Kazmi AA. 2009. Rotary drum composting of vegetable waste and tree leaves. Bioresour Technol. 100:6442-6450.

Madejon P, Xiong J, Cabrera F, Madejon E. 2014. Quality of trace element contamined soils amanded with compost under fast growing tree Paulownia fortunei plantation. J Environ Manage. 144:176-185.

Martinez-blanco, Munoz P, Anton A, Rieradevall J. 2009. Life cycle assesment of the use of compost from municipal organic waste for fertilization of tomato crops. Resour Conserv Recylcle. 53:340-351.

Oktavia D, Setiadi Y, Hilwan I. 2012. The comparison of soil properties in heath forest and psot-tin mining 
land: basic for ecosystem restoration. Procedia Env Sci. 28:124-131.

PT Bukit Asam. 2013. Analisis dampak lingkungan hidup PT Bukit Asam (Persero), TBK Sumatera Selatan. Palembang (ID): PT Bukit Asam.

[Permentan] Peraturan Menteri Pertanian Nomor 70 Tahun 2011 Tentang Pupuk Organik, Pupuk Hayati dan Pembenah Tanah. Jakarta (ID): Kementerian Pertanian.

Rodriguez-Vila A, Asensio V, Forjan R, Covelo EF. 2015. Chemical fractionation of $\mathrm{Cu}, \mathrm{Ni}, \mathrm{Pb}$ and $\mathrm{Zn}$ in mine soil amandemed with compost and biochar and vegetated with Brassica juncea L. J Geochem Explor. 158:74-81.

Rynk R, van de Kamp M, Wilson GB, Singley ME, Richard TL, Kolega JJ, Gouin FR, Laiberty, Jr L, Kay D, Murphy DW, Hoitink HAJ, Brinton WF. 1992. On-farm composting handbook. New York (USA): Northeast Regional Agricultural Engineering Service

Sevilla-Perea A, Mingorance MD. 2015. Field approach to mining-dump revegetation by aplication sludge cocompost and comercial biofertilizer. $J$ Environ Manage. 158:95-102.

Sizmur T, Palumbo-Roe B, Hodson ME. 2011. Impact of earthworms on trace element solubility in contamined mine soils amanded with green waste compost. Environ Pollut. 159:1852-1960.

Thambirajah JJ, Zukali MD, Hashim MA. 1995. Microbiological and biochemical changes during the composting of oil palm empty-fruit bunches : effect of nitrogen suplementation on the substrate. Bioresour Technol. 52:133-144.
Tejada M, Heranandez MT, Garcia C. 2009. Soil restoration using composted plant residues : effect on soil properties. Soil Tillage Res. 102:109-117.

Tuomela M, Vikman M, Hatakka A, Itavaara M. 2000. Biodegradation of lignin in a compost environment : a review. Bioresoul Technol. 72: 169-183.

Wasis B, Sandrasari A. 2011. Pengaruh pemberian pupuk kompos terhadap pertumbuhan semai mahoni (Swietenia macrophylla King.) pada media tanah bekas tambang emas (tailing). JST. 3(01): 109-112.

Yadav S, Chandra R. 2011. Heavy metals accumulation and ecophysiological effect on Typha angustifolia $\mathrm{L}$. and Cyperus esculentus L. growing in distillery and tannery effluent polluted natural wetland site, Unnao, India. Environ Earth Sci. 62:1235-1243

Yu S, Clark OG, Leonard JJ. 2009. Influence of free air space on microbial kinetics in passively aerated compost. Bioresour Technol. 100:782-790.

Yuwono D. 2007. Kompos. Jakarta (ID): Penebar Swadaya

Yuwono AS, Ichwan N, Saptomo SK. 2013. Implementasi konsep "zero waste production management" bidang pertanian: pengomposan jerami padi organik dan pemanfaatannya. Jurnal Bumi Lestari. 13(02): 366373.

Zhang L, Sun X. 2016. Influence of bulking agents on physical, chemical, and microbiological properties during the two-sta. 